by droughts, and subsequently, at times by famines. Thus, taking the period from 1877 to 1889 , there was rain from the minus pulse in 1877-78-79 (part); no rain pulse in 1879 (part)-80-81 (part); rain from plus pulse 1881 (part) 82-83-84 (part); no rain pulse in 1884 (part)-86-87; and rain from the minus pulse in 1887 (part)-88-89. All the Indian famines since 1836 had occurred in these intervals, carried back in time on the assumption of an 11-year cycle. Thus, taking 1880 as the central year on the ascending curve, it was itself a year of famine in Madras and the North-West Provinces; also

$$
\begin{array}{r}
1880-11=1869, \text { N.W.P. famine }(1868-69) \\
1869-11=1858, \text { N.W.P. famine }(1860) \\
1858-11=1847, \\
1847-11=1836, \text { Great famine in Upper India } \\
(1837-38) . \quad \text { Again, taking } 1885-1886 \text { as the central } \\
\text { years on the descending curve :- } \\
1885-86, \text { Bengal and Madras famines } \\
(1884-85) \\
(1885-86)-11=1874-75, \text { N. W.P. famine }(1873-74) \\
\text { Bombay famine }(1875-76) \\
\text { Bombay and Upper India } \\
\text { famines }(1876-77)
\end{array}
$$

It was clear from this table that if as much had been known in 1836 as was known now, the probability of famines at all the subsequent dates indicated might have been foreseen. The dates might also be carried forward from 1880 ; thus-

$$
\begin{aligned}
1880+11=1891, & \text { N.W.P. famine }(1890) \\
& \text { Madras, Bombay and Bengal } \\
& \text { famines }(1891-92) \\
(1885-1886)+11= & 1896-97, \text { General famine. }
\end{aligned}
$$

Famine years in India were usually years of low flood in Egypt, and it might be pointed out that the highest Niles followed, at an interval of one or two years, the years of the plus and minus pulses. As to the great Indian famine of last year, the widened line curves, so far from having crossed in 1897 or 1898, as they ought according to the few precedents available, had not crossed even now ; in other words, the condition of ordinary solar mean temperature had not even yet been reached. Now India in a normal cycle was supplied from the southern ocean during the minimum sunspot period, and the rain was due to some pressure effect brought about in high southern latitudes by the sun at minus temperature. But as this temperature condition was not reached in 1899, as it would have been in a normal year, the rain failed. Thus the only abnormal famine recorded since 1836 occurred precisely at the time when an abnormal effect of an unprecedented maximum of solar temperature was revealed by the study of the widened lines.

\section{THE ULKE COLLECTION OF COLEOPTERA.}

THE collection of Coleoptera brought together during the last 50 years by Henry Ulke, of Washington, D. C., has been purchased by the Carnegie Museum, of Pittsburgh, Pa.

Henry Ulke, artist, musician, entomologist-a noticeable character from many points of view-having passed beyond his eightieth birthday, has given up his entomological collections, but by no means his interest in this branch of science. The writer met him the other day in Washington, active, alert, clear-eyed, with a complexion like a child's, and asked him how it was that he retained his youth at 10 years beyond the allotted space of life. The reply was wittily characteristic and contained a characteristic truth : "In the first place," said Ulke, "I was very careful in my choice of parents ; and in the second place, my love of Nature has kept me constantly in the woods and fields throughout all my life."

The Ulke collection of Coleoptera is one of the largest and, historically and in other 
ways, one of the most important collections in the United States. It represents the lifelong work of one of our most experienced and most assiduous collectors. Its foundation dates back nearly half a century, and up to within the past few years Mr. Ulke spared no effort to increase it by collecting or by exchanging. In the early days of the great transcontinental surveys, the Smithsonian Institution had not begun to make collections of insects, and as a result much of the material picked up by the naturalists connected with these surveys fell into $\mathrm{Mr}$. Ulke's hands. He was never a publishing entomologist, and the writer believes that only one published paper bears his name. That was a report on the beetles collected by one of the Wheeler survey expeditions. The collection numbers perhaps 125,000 specimens, and its large number of speciesmore than 11,000-as well as the large series of specimens representing each species, rendered this collection for many years preeminent among other collections. It is, in fact, only within the past 15 or 20 years, when careful collecting methods have become more generally adopted and when railroads have made all parts of the country more accessible, that other large private collections have been formed. Ulke early appreciated the importance of large series, and at a time when other collectors were gathering beetles as a boy collects postage stamps, one or two specimens representing a species, Ulke had his long rows of specimens indicating variation within specific limit and variation due to geographic and other environmental dissimilarities.

A distinguishing feature of the collection is the uniformly perfect preservation of the specimens as well as the exquisite and painstaking care with which even the most delicate specimens are prepared and thus rendered available for study. In this respect the collection is still unapproached by any other.
How much the progress of North American coleopterology is indebted to this collection can readily be seen from the writings of systematists, and in fact there is not a single worker in this field who has not drawn material from the Ulke collection. The liberality with which Mr. Ulke has always placed his collection at the disposal of students and workers is well known and has been acknowledged in print over and over again. The collection was employed by Le Conte and by Horn in the preparation of their various monographs and revisions, and has been similarly used by Dietz, Hayward, Matthews and others. That the collection has thereby been increased in scientific value goes without saying and besides a large number of actual types the collection contains several thousand specimens which are cotypical in value.

The Carnegie Museum, at Pittsburgh, already contains the collection of Coleoptera of the late Dr. John Hamilton, and it is sincerely to be congratulated upon this last important addition to its entomological treasures. This is the first time, I believe, that a private collection made in our Eastern States finds its way west of the Allegheny Mountains, and while the writer sincerely regrets that the collection could not remain in Washington as the property of the U. S. National Museum, he feels consolation in the firm conviction that it will be well cared for at Pittsburgh, at least so long as Dr. Holland remains Director of the Carnegie Museum (and may that be for many years to come!), and will continue to to be a source of information and study for the younger generation of coleopterists.

The Museum also contains, as is well known, the superb collection of Lepidoptera brought together by Dr. Holland, and this last collection cannot fail to place the Carnegie Museum in a group of four public institutions which contain collections of insects of great extent and value and 
which will be consulted by students for generations to come. The other three great collections are to be found at the Museum of Comparative Zoology, at Cambridge, Mass.; the Academy of Natural Sciences, at Philadelphia, Pa.; and the U.S. National Museum, Washington, D. C.

\section{O. HowaRD.}

\section{SCIENTIFIC BOOKS.}

American Hydroids, Part I, The Plumularidæ. By C. C. Nutring. Washington, 1900. Published by the Smithsonian Institution. Pp. 285 ; pls. 34.

We are accustomed to think of social life and the division of labor as being especially characteristic of highly organized beings, such as ourselves among the vertebrates, and the ants among the arthropods; but as a matter of fact socialism was invented and put into practice very early in the history of terrestrial life, among creatures not so very far removed from the most primitive types known to us. Professor Nutting, in the splendid monograph now under review, tells us (p. 46) that "Hydroids are exceedingly low in their organization and exhibit in several respects the appearance of loosely aggregated assemblages of cells which are individually much like protozoa," and yet he describes and figures the wonderfully differentiated individuals or 'persons' which make up the beautiful and complicated feather-like colonies of these animals. That there would be some differentiation for reproductive ends we might well expect, but the Plumularidæ keep a standing army of remarkably constituted individuals, supported by the common purse, and fighting for the common weal. Listen here to Professor Nutting :

"As to the morphological significance of the sarcostyles, all of the more recent authorities, except Jickeli, regard them as degenerate individuals of the colony, or as 'fighting persons.' That they are individuals or 'persons' is a matter hardly admitting of doubt; but it may well be questioned whether they are degenerate persons or not, and an argument might be constructed which would go to show that instead of being degenerate individuals they are in fact very highly specialized persons. Specialization is indicated when the structure has. departed from the original type in order to become adapted to more definite and exclusive function. It would seem that the sarcostyles have done this very thing-departed from the original type (Protohydra ?), and become morphologically differentiated into individuals having the defnite function of defense, in most cases, and of prehension by means of adhesive cells "in others" (p. 28).

All of which teaches us that, after all, living protoplasm is the wonderful thing; granting it, the varied and complicated manifestations of life may be said to follow naturally and inevitably, their extent and variety dependent on warmth and moisture, time and space, but their essential nature what it was when life first appeared upon the earth.

These things may sound trite; but while we talk glibly of differentiation and evolution, we do not always descend from the abstract to the concrete, and realize the actual facts. Professor Nutting's monograph should have this value to the general zoologist and the teacher of science, that it brings them as nearly into contact with the things themselves and their way of life as may be possible without a prolonged and special study of the group. The study of types may give us a certain knowledge of structure, but without a real insight into life-histories, we miss most of the fun, and may. therefore be thankful to be invited to partake of the provender so laboriously gathered for our beuefit.

In 1862, the elder Agassiz recognized only three Plumularidæ from the coasts of the United States. To-day Professor Nutting makes us acquainted with 121 American species, eight of which, however, are not found north of the Isthmus of Panama. Of the 121, no less than 52 have been first made known by Professor Nutting himself. Most of the species come from the West Indies, and it seems rather remarkable that only ten are reported from the whole Pacific coast of North America. Surely more careful collecting off the coasts of Southern and Lower California should bring to light a number of new forms.

T. D. A. Cockerell. 